\title{
Primorskyibacter sedentarius gen. nov., sp. nov., a novel member of the class Alphaproteobacteria from shallow marine sediments
}

Correspondence

Lyudmila A. Romanenko Iro@piboc.dvo.ru

\author{
Lyudmila A. Romanenko, ${ }^{1}$ Naoto Tanaka, ${ }^{2}$ Vasily I. Svetashev ${ }^{3}$ \\ and Valery V. Mikhailov ${ }^{1}$
}
${ }^{1}$ Pacific Institute of Bioorganic Chemistry, Far-Eastern Branch, Russian Academy of Sciences, 690022 Vladivostok, Prospect 100 Let Vladivostoku, 159, Russia
${ }^{2}$ NODAl Culture Collection Center, Tokyo University of Agriculture, 1-1-1 Sakuragaoka, Setagaya-ku, Tokyo 156-8502, Japan
${ }^{3}$ Institute of Marine Biology, Far-Eastern Branch, Russian Academy of Sciences, 690041 Vladivostok, Russia

Shallow marine environments are significant as natural harbours of unusual micro-organisms that are capable of dwelling under the peculiar conditions provided by the seashore habitat. The Roseobacter clade (order Rhodobacterales, class Alphaproteobacteria) comprises a large group of bacteria (Garrity et al., 2005, 2006) that are probably one of the most significant components of microbial communities that colonize shallow marine waters and sediments (Buchan et al., 2005). In this study, we report the isolation and phenotypic and phylogenetic characterization of two novel strains, designated KMM

Abbreviations: Bchl, bacteriochlorophyll; FAME, fatty acid methyl ester. The GenBank/EMBL/DDBJ accession numbers for the 16S rRNA gene sequences of strains KMM 9015 and KMM 9018 ${ }^{\top}$ are AB550559 and AB550558, respectively.

Two supplementary figures are available with the online version of this paper.
9015 and $\mathrm{KMM} 9018^{\mathrm{T}}$, that were found during a study of bacteria inhabiting shallow sediments of the Sea of Japan. Phylogenetic analysis of $16 \mathrm{~S}$ rRNA gene sequences revealed that the novel isolates were closely related to members of the Roseobacter clade, including the genera Marinovum, Leisingera, Phaeobacter and Thalassobius, where they formed a separate line adjacent to Marinovum algicola. Based on distinctive phenotypic characteristics and phylogenetic distance, a novel genus and species are described to accommodate strains KMM 9015 and KMM $9018^{\mathrm{T}}$.

Strains KMM 9015 and KMM $9018^{\mathrm{T}}$ were isolated from the same shallow sediment sample, collected from Peter the Great Bay, Sea of Japan, Russia ( $\left.42^{\circ} 40.108^{\prime} \mathrm{N} 131^{\circ} 12.983^{\prime} \mathrm{E}\right)$, as described previously (Romanenko et al., 2003). The strains were grown aerobically on marine 2216 agar (MA) or in marine broth $(\mathrm{MB})$ and were stored at $-80{ }^{\circ} \mathrm{C}$ in $\mathrm{MB}$ supplemented with $30 \%(\mathrm{v} / \mathrm{v})$ glycerol. Motility was determined by the hanging drop method as described by 
Gerhardt et al. (1994). Cells were observed by oilimmersion phase-contrast microscopy (AX70; Olympus) using 2-day cultures grown on MA at $25^{\circ} \mathrm{C}$. Gram staining, oxidase and catalase, hydrolysis of gelatin, casein, DNA and Tweens 20, 40 and 80 and production of $\mathrm{H}_{2} \mathrm{~S}$ from thiosulfate were tested according to standard methods (Smibert \& Krieg, 1994). Acid production from carbohydrates was examined using oxidation/fermentation medium as described by Leifson (1963). Requirement for and tolerance of $\mathrm{NaCl}$ were tested on artificial seawater (ASW)based medium using various concentrations of $\mathrm{NaCl}$ in the range $0-20 \%$, supplemented with $\left(1^{-1}\right) 10.0 \mathrm{~g}$ Bacto peptone, $2.0 \mathrm{~g}$ yeast extract, $0.028 \mathrm{~g} \mathrm{FeSO}_{4}$ and $15.0 \mathrm{~g}$ agar. ASW was prepared as described by Bruns et al. (2001) and contained (per litre distilled water) $23.6 \mathrm{~g} \mathrm{NaCl}, 4.53 \mathrm{~g}$ $\mathrm{MgCl}_{2} \cdot 6 \mathrm{H}_{2} \mathrm{O}, 3.9 \mathrm{~g} \mathrm{Mg}_{2} \mathrm{SO}_{4} \cdot 7 \mathrm{H}_{2} \mathrm{O}, 0.64 \mathrm{~g} \mathrm{KCl}$ and $1.3 \mathrm{~g}$ $\mathrm{CaCl}_{2} \cdot 2 \mathrm{H}_{2} \mathrm{O}$. In addition, strains were tested for growth on the above medium containing $\mathrm{NaCl}$ alone without any of the sea salts components, $\mathrm{MgCl}_{2}, \mathrm{Mg}_{2} \mathrm{SO}_{4}, \mathrm{KCl}$ and $\mathrm{CaCl}_{2}$. The ability to grow in the presence of organic substrates as sole carbon and energy sources was tested for 3 weeks on ASW-based medium supplemented with $\left(1^{-1}\right)$ $2 \mathrm{~g} \mathrm{NH}_{4} \mathrm{Cl}, 0.5 \mathrm{~g}$ yeast extract and $0.4 \%$ carbon source. Growth was considered as negative if it was equal to or less than that in the negative control to which no carbon source had been added. Growth at $4-45{ }^{\circ} \mathrm{C}$ and $\mathrm{pH} 4.0-13.0$ and antibiotic resistance were studied as described previously (Romanenko et al., 2003, 2005). In addition, biochemical tests were carried out using API ZYM, API 32GN and API $20 \mathrm{NE}$ test kits (bioMérieux) according to the manufacturer's instructions, except that the cultures were suspended in ASW. Production of bacteriochlorophyll (Bchl) $a$ was tested spectrophotometrically in methanolic extracts of cells grown on MA and in MB in the dark as described by Lafay et al. (1995). For polar lipid and fatty acid analyses, strains KMM 9015 and $\mathrm{KMM} 9018^{\mathrm{T}}$ were cultivated on MA at $28{ }^{\circ} \mathrm{C}$ for 3 days, and lipids were extracted using the extraction method of Folch et al. (1957). Two-dimensional TLC of polar lipids was carried out on silica gel $60 \mathrm{~F}_{254}$ plates $(10 \times 10 \mathrm{~cm}$; Merck) using chloroform/methanol/ water $(65: 25: 4$, by vol.) for the first direction and chloroform/methanol/acetic acid/water $(80: 12: 15: 4$, by vol.) for the second (Collins \& Shah, 1984). Fatty acid methyl esters (FAMEs) were prepared according to the procedure of the Microbial Identification System (MIDI) (Sasser, 1990). Analysis of FAMEs was performed using a GC-17A chromatograph (Shimadzu) equipped with a capillary column $(30 \mathrm{~m} \times 0.25 \mathrm{~mm}$ i.d. $)$ coated with Supecowax-10 and SPB- 5 phases (Supelco). Identification of FAMEs was accomplished by determining equivalent chain-length values and comparing the retention times of the samples to those of standards. In addition, FAMEs were analysed using a GLC-MS Shimadzu GC-MS model QP5050 (column MDM-5S; temperature program from 140 to $250{ }^{\circ} \mathrm{C}$, at a rate of $2{ }^{\circ} \mathrm{C} \mathrm{min}^{-1}$ ). Cells for respiratory lipoquinone analysis were obtained from $\mathrm{MB}$ cultures grown at $25{ }^{\circ} \mathrm{C}$. Isoprenoid quinones were analysed as described by Collins \& Shah (1984). Methanol/2-propanol
$(2: 1, \mathrm{v} / \mathrm{v})$ was used as the mobile phase and quinones were detected at $270 \mathrm{~nm}$. The DNA base composition was determined as described by Marmur \& Doty (1962) and Owen et al. (1969). DNA-DNA hybridization between strains KMM 9015 and KMM $9018^{\mathrm{T}}$ was carried out by the method of Ezaki et al. (1989). The 16S rRNA gene sequences of strains KMM 9015 and KMM $9018^{\mathrm{T}}$, containing 1438 and $1436 \mathrm{nt}$, respectively, were determined as described by Shida et al. (1997). The sequences obtained were compared with $16 \mathrm{~S}$ rRNA gene sequences retrieved from the EMBL/GenBank/DDBJ databases by using the FASTA program (Pearson \& Lipman, 1988). Phylogenetic analysis of $16 \mathrm{~S}$ rRNA gene sequences was performed using the software package MEGA4 (Tamura et al., 2007) after multiple alignment of the data by CLUSTAL_x (version 1.83; Thompson et al., 1997). Phylogenetic trees were constructed by the neighbour-joining and maximumparsimony methods and distances were calculated according to Kimura's two-parameter model. The robustness of phylogenetic trees was estimated by bootstrap analysis of 1000 replicates.

Comparative 16S rRNA gene sequence analysis showed that the novel strains KMM 9015 and KMM $9018^{\mathrm{T}}$ were closely related to each other, with a sequence similarity of $99.9 \%$. Their closest phylogenetic neighbours were the type strains of Marinovum algicola (95.8 and $95.9 \%$ sequence identity, respectively), Leisingera methylohalidivorans (95.7 and 95.8\%), Phaeobacter gallaeciensis (94.9 and 95.0\%) and Thalassobius mediterraneus (96.3 and 96.2\%). Different treeing algorithms [neighbour-joining (Fig. 1) and maximum-parsimony (Supplementary Fig. S1, available in IJSEM Online)] positioned strains KMM 9015 and KMM $9018^{\mathrm{T}}$ within the Roseobacter lineage of the class Alphaproteobacteria as a separate branch adjacent to Marinovum algicola [formerly Roseobacter algicola and Ruegeria algicola (Lafay et al., 1995; Uchino et al., 1998, 1999); reclassified by Martens et al. (2006)]. The low values of sequence similarity to related alphaproteobacteria demonstrated that strains KMM 9015 and KMM $9018^{\mathrm{T}}$ could be representatives of a novel genus. The DNA-DNA relatedness between strains KMM 9015 and $\mathrm{KMM} 9018^{\mathrm{T}}$ was found to be $71 \%$, supporting their assignment to the same species (Wayne et al., 1987). Physiological, biochemical and chemotaxonomic characteristics of strains KMM 9015 and KMM $9018^{\mathrm{T}}$ are given in Tables 1 and 2, Supplementary Fig. S2 and the genus and species descriptions. Strains KMM 9015 and $\mathrm{KMM} 9018^{\mathrm{T}}$ were phenotypically identical, being Gram-negative, strictly aerobic, oxidase- and catalasepositive, non-fermentative, heterotrophic, non-motile, rod-shaped bacteria that were enlarged at one pole due to the budding process (Fig. 2). It should be mentioned

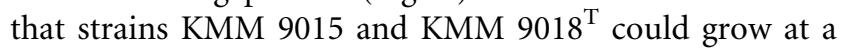
relatively narrow range of $\mathrm{pH}$ 6.5-9.5. Both strains gave negative results for carbon source assimilation in API $32 \mathrm{GN}$ and API 20NE tests, but they could grow on Dglucose and most carbohydrates, organic and amino acids when they were tested by a conventional method applying 


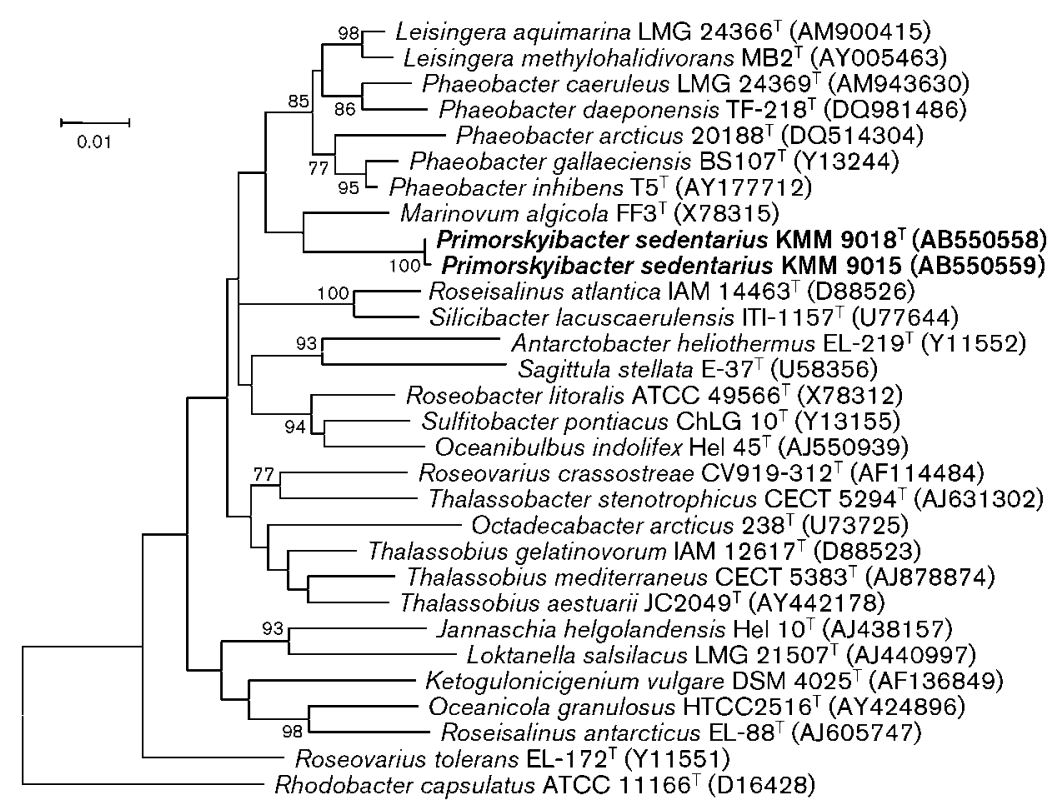

Fig. 1. Neighbour-joining phylogenetic tree based on 16S rRNA gene sequences available from the GenBank/EMBL/DDBJ databases (accession numbers in parentheses) showing the relationship of isolates $\mathrm{KMM} 9015$ and $\mathrm{KMM} 9018^{\top}$ and related genera of the class Alphaproteobacteria. Phylogenetic analysis was performed using the software package MEGA4 (Tamura et al., 2007) after multiple alignment of the data by CLUSTAL_X (version 1.83; Thompson et al., 1997). Bootstrap values based on 1000 replications are given as percentages at branching points; numbers indicate percentages greater than $70 \%$. Bar, 0.01 substitutions per nucleotide position.
ASW-based medium (Table 1). Chemotaxonomically, the major isoprenoid quinone was Q-10 and the polar lipids consisted of phosphatidylcholine, phosphatidylethanolamine, phosphatidylglycerol and an unknown lipid in both strains (Supplementary Fig. S2). Fatty acid analysis revealed a high content of $\mathrm{C}_{18: 1} \omega 7 c(86.85$ and $85.79 \%)$ followed by 11-methyl $\mathrm{C}_{18: 1} \omega 7 c(5.48$ and $5.69 \%)$ in both strains (Table 2).

The chemotaxonomic properties of strains KMM 9015 and $\mathrm{KMM} 9018^{\mathrm{T}}$ (ubiquinone Q-10, the predominance of $\mathrm{C}_{18: 1} \omega 7 c$, the presence of phosphatidylcholine, phosphatidylethanolamine and phosphatidylglycerol and DNA $\mathrm{G}+\mathrm{C}$ contents of $60.2-61.9 \mathrm{~mol} \%$ ) are in agreement with those reported for phylogenetically related genera of the Roseobacter clade, class Alphaproteobacteria. Strains KMM 9015 and KMM $9018^{\mathrm{T}}$ can be distinguished from their phylogenetic relatives by the presence of diphosphatidylglycerol and the identity of the hydroxy fatty acids present in trace amounts. In addition, unlike Marinovum algicola, strains KMM 9015 and KMM $9018^{\mathrm{T}}$ contained $\mathrm{C}_{16: 0}$ and a small amount of $\mathrm{C}_{17: 0}$ (Table 2). The phylogenetic distinctiveness found for strains KMM 9015 and $\mathrm{KMM} 9018^{\mathrm{T}}$ was supported by a combination of phenotypic characteristics that differentiate them from closely related bacteria. The two isolates could be distinguished from their closest relatives in non-motility (except Thalassobius mediterraneus), cellular morphology and cell division by budding, pigmentation, the ability to hydrolyse DNA, aesculin (except Marinovum algicola) and Tween 80 and carbon source utilization. Based on their distinctive phenotypic characteristics and phylogenetic distance, strains KMM 9015 and $\mathrm{KMM} 9018^{\mathrm{T}}$ are considered to represent a novel genus and species, for which the name Primorskyibacter sedentarius gen. nov., sp. nov. is proposed.

\section{Description of Primorskyibacter gen. nov.}

Primorskyibacter (Pri.mor'sky.i.bac'ter. N.L. n. Primorsky yos Primorsky Kray, a Far-Eastern region of the Russian Federation, where the first strains were isolated; N.L. masc. n. bacter rod; N.L. masc. n. Primorskyibacter rod isolated from Primorsky Kray).

Gram-negative, strictly aerobic, oxidase- and catalase-positive, rod-shaped bacteria that are enlarged at one pole due to cell division by budding. Chemo-organoheterotrophic. Sodium ions are essential for growth. The predominant isoprenoid quinone is Q-10. Polar lipids include phosphatidylcholine, phosphatidylethanolamine, phosphatidylglycerol, diphosphatidylglycerol and an unknown lipid. The major fatty acid is $\mathrm{C}_{18: 1} \omega 7 c$, followed by 11-methyl $\mathrm{C}_{18: 1} \omega 7 c$. Known strains have been isolated from marine environments. On the basis of $16 \mathrm{~S}$ rRNA gene sequence analysis, the genus represents a separate branch within the Alphaproteobacteria closely related to the genera Marinovum, Leisingera, Phaeobacter and Thalassobius. The type species of the genus is Primorskyibacter sedentarius.

\section{Description of Primorskyibacter sedentarius sp. nov.}

Primorskyibacter sedentarius (se.den.ta'ri.us. L. masc. adj. sedentarius sedentary, non-motile).

In addition to the properties given in the genus description, the species is characterized as follows. Cells are $1.2-1.5 \mu \mathrm{m}$ in diameter and $2.5-3.5 \mu \mathrm{m}$ long. Nonmotile. Produces whitish, opaque, smooth and shiny colonies with regular edges, $2-3 \mathrm{~mm}$ in diameter, on MA. Bchl $a$ is not produced. Growth occurs at $0.5-8 \%$ $\mathrm{NaCl}(\mathrm{w} / \mathrm{v})$ and is optimal in $3-5 \% \mathrm{NaCl}$. Grows in/on basal medium containing $\mathrm{NaCl}$ alone without any of the 
Table 1. Differential characteristics of strains $\mathrm{KMM} 9015$ and $\mathrm{KMM} 9018^{\top}$ (Primorskyibacter sedentarius gen. nov., sp. nov.) and related members of the class Alphaproteobacteria

Strains: 1 and 2, KMM 9015 and KMM 9018 ${ }^{\mathrm{T}}$ (data from the present study); 3, Marinovum algicola DSM 10251 ${ }^{\mathrm{T}}$ (data from Martens et al., 2006; Ruiz-Ponte et al., 1998; Lafay et al., 1995; Labrenz et al., 1999); 4, Leisingera methylohalidivorans DSM 14336 ${ }^{\mathrm{T}}$ (Schaefer et al., 2002; Vandecandelaere et al., 2008); 5, Leisingera aquimarina CCUG $55860^{\mathrm{T}}$ (Vandecandelaere et al., 2008); 6, Phaeobacter inhibens DSM $16374^{\mathrm{T}}$ (Martens et al., 2006; Vandecandelaere et al., 2008); 7, Phaeobacter gallaeciensis CIP 105210 (Ruiz-Ponte et al., 1998; Martens et al., 2006); 8, Phaeobacter daeponensis $\mathrm{TF}-218^{\mathrm{T}}$ (Yoon et al., 2007; Vandecandelaere et al., 2008); 9, Thalassobius mediterraneus CIP 108400 ${ }^{\mathrm{T}}$ (Arahal et al., 2005); 10, Thalassobius gelatinovorus CECT $4357^{\mathrm{T}}$ (Arahal et al., 2005; Rüger \& Höfle, 1992). W, Weak reaction; NG, no growth; ND, no data available.

\begin{tabular}{|c|c|c|c|c|c|c|c|c|c|}
\hline Characteristic & 1 and 2 & 3 & 4 & 5 & 6 & 7 & 8 & 9 & 10 \\
\hline Pigmentation ${ }^{*}$ & WH & $\mathrm{BG} / \mathrm{PH}$ & - & $\mathrm{DBG} / \mathrm{P}$ & $\mathrm{BR}$ & $\mathrm{BR}$ & - & - & $\mathrm{BG} / \mathrm{BR}$ \\
\hline Bchl $a$ & - & - & - & ND & - & - & - & ND & $\mathrm{ND}$ \\
\hline \multicolumn{10}{|l|}{ Growth at: } \\
\hline $4{ }^{\circ} \mathrm{C}$ & + & - & + & + & + & - & + & - & + \\
\hline $37{ }^{\circ} \mathrm{C}$ & + & + & - & + & - & + & + & + & + \\
\hline Nitrate reduction & - & - & - & - & - & - & + & - & + \\
\hline \multicolumn{10}{|l|}{ Utilization of: } \\
\hline Glucose & + & + & - & - & + & + & + & + & - \\
\hline Rhamnose & + & - & - & ND & - & - & ND & ND & - \\
\hline Maltose & + & + & - & - & + & + & - & $\mathrm{W}$ & + \\
\hline Acetate & + & - & - & $\mathrm{ND}$ & + & + & + & + & + \\
\hline \multicolumn{10}{|l|}{ Hydrolysis of: } \\
\hline DNA & + & - & - & - & - & - & - & ND & ND \\
\hline Aesculin & + & + & - & - & - & ND & - & $\mathrm{ND}$ & $\mathrm{ND}$ \\
\hline Gelatin & - & + & - & $\mathrm{w}$ & - & - & - & - & + \\
\hline Tween 80 & + & - & - & - & - & - & - & NG & $\mathrm{w}$ \\
\hline Starch & - & $\mathrm{w}$ & + & - & - & - & - & - & - \\
\hline DNA G $+\mathrm{C}$ content $(\mathrm{mol} \%)$ & $60.2,61.9 \dagger$ & 60 & 60.5 & 61.4 & 55.7 & $57.6-58.0 \ddagger$ & 64.9 & 57 & 59 \\
\hline
\end{tabular}

${ }^{*} \mathrm{BG}$, Beige; BR, brown; DBG, dark beige; $\mathrm{P}$, pink; $\mathrm{PH}$, pinkish; WH, whitish; -, not pigmented.

$\dagger$ Data for KMM 9015 and KMM $9018^{\mathrm{T}}$, respectively.

\$Range of values for four strains, including the type strain (Ruiz-Ponte et al., 1998).

sea salts components $\mathrm{MgCl}_{2}, \mathrm{KCl}, \mathrm{CaCl}_{2}$ and $\mathrm{MgSO}_{4}$. Grows at $4-39{ }^{\circ} \mathrm{C}$, with optimum growth at $25-30{ }^{\circ} \mathrm{C}$; weak growth at $40{ }^{\circ} \mathrm{C}$, and no growth above $40{ }^{\circ} \mathrm{C}$. The $\mathrm{pH}$ range for growth is 6.5-9.5, with optimum growth at pH 7.5-8.5. Negative for hydrolysis of casein, gelatin, chitin and starch and $\mathrm{H}_{2} \mathrm{~S}$ production. Positive for hydrolysis of DNA, Tweens 80, 40 and 20 and L-tyrosine. On L-tyrosine-containing medium, brown diffusible pigments are produced and a clearance zone is formed. No acid production from D-glucose, maltose, D-galactose, sucrose, lactose, D-mannose, cellobiose, D-xylose, L-arabinose, L-rhamnose, melibiose, D-ribose, fructose, L-sorbose, raffinose, $\mathrm{N}$-acetylglucosamine, glycerol, myo-inositol or Dmannitol. In API 20NE strips, positive for the PNPG test and aesculin hydrolysis and negative for nitrate reduction, indole production, glucose acidification under anaerobic conditions, gelatin hydrolysis, arginine dihydrolase, urease and assimilation of D-glucose, L-arabinose, D-mannose, D-mannitol, $\mathrm{N}$-acetylglucosamine, maltose, D-gluconate, caprate, adipate, L-malate, citrate and phenylacetate. In ID32 GN strips, negative for assimilation of L-rhamnose, $\mathrm{N}$-acetylglucosamine, D-ribose, inositol, sucrose, maltose, itaconic acid, suberic acid, sodium malonate, sodium acetate, lactic acid, L-alanine, potassium 5-ketogluconate, glycogen, 3-hydroxybenzoic acid, L-serine, D-mannitol, D-glucose, salicin, melibiose, L-fucose, D-sorbitol, L-arabinose, propionic acid, capric acid, valeric acid, trisodium citrate, L-histidine, potassium 2-ketogluconate, 3-hydroxybutyric acid, 4-hydroxybenzoic acid and L-proline. In API ZYM tests, positive for alkaline phosphatase, esterase (C4), esterase lipase (C8), leucine arylamidase, acid phosphatase and $\alpha$-glucosidase, weakly positive for naphthol-AS-BI-phosphohydrolase and negative for lipase (C14), valine arylamidase, cystine arylamidase, trypsin, $\alpha$-chymotrypsin, $N$-acetyl$\beta$-glucosaminidase, $\alpha$-galactosidase, $\beta$-galactosidase, $\beta$-glucuronidase, $\beta$-glucosidase, $\alpha$-mannosidase and $\alpha$-fucosidase. Positive for utilization of D-glucose, maltose, L-rhamnose, Larabinose, sucrose, fructose, raffinose, cellobiose, D-mannitol, 
Table 2. Fatty acid and polar lipid profiles of strains $\mathrm{KMM} 9015$ and $\mathrm{KMM} 9018^{\top}$ and related members of the class Alphaproteobacteria

Strains: 1, KMM 9015; 2, KMM 9018 (data in columns 1 and 2 from the present study); 3, Marinovum algicola DSM 10251 ${ }^{\mathrm{T}}$ (Martens et al., 2006); 4, Leisingera methylohalidivorans DSM $14336^{\mathrm{T}}$ (Schaefer et al., 2002); 5, Leisingera aquimarina CCUG 55860 ${ }^{\mathrm{T}}$ (Vandecandelaere et al., 2008); 6, Phaeobacter inhibens DSM $16374^{\mathrm{T}}$ (Martens et al., 2006); 7, Phaeobacter gallaeciensis CIP 105210 ${ }^{\mathrm{T}}$ (Martens et al., 2006); 8, Phaeobacter daeponensis TF-218 ${ }^{\mathrm{T}}$ (Yoon et al., 2007); 9, Thalassobius mediterraneus CIP $108400^{\mathrm{T}}$ (Arahal et al., 2005); 10, Thalassobius gelatinovorus $\mathrm{CECT} 4357^{\mathrm{T}}$ (Arahal et al., 2005). Data for fatty acids are percentages of the total fatty acid content (-, not detected/not reported); polar lipids are indicated as present or absent. ND, No data available; ECL, equivalent chain length.

\begin{tabular}{|c|c|c|c|c|c|c|c|c|c|c|}
\hline Component & 1 & 2 & 3 & 4 & 5 & 6 & 7 & 8 & 9 & 10 \\
\hline \multicolumn{11}{|l|}{ Fatty acid } \\
\hline $\mathrm{C}_{10: 0} 3-\mathrm{OH}$ & - & - & 1.15 & 1.83 & 2.0 & 1.71 & 1.86 & 1.7 & 1.9 & 1.5 \\
\hline $\mathrm{C}_{12: 1} 3-\mathrm{OH}$ & 0.52 & 0.57 & - & - & - & - & - & - & 4.0 & - \\
\hline $\mathrm{C}_{14: 1}$ & - & - & - & 2.27 & & 2.19 & 2.14 & - & - & - \\
\hline iso- $\mathrm{C}_{14: 1} \mathrm{E}$ & - & - & - & - & 11.6 & - & - & - & - & - \\
\hline $\mathrm{C}_{12: 0}$ & - & - & - & - & - & - & - & 1.2 & - & 3.1 \\
\hline$C_{16: 0}$ & 3.09 & 3.34 & - & 5.08 & 3.5 & 3.83 & 3.79 & 8.6 & 3.0 & 2.9 \\
\hline $\mathrm{C}_{16: 0} 2-\mathrm{OH}$ & - & - & - & 6.97 & 4.2 & 3.10 & 3.90 & 5.6 & - & - \\
\hline $\mathrm{C}_{17: 0}$ & 0.95 & 1.52 & - & - & - & - & - & 0.6 & - & - \\
\hline $\mathrm{C}_{18: 1} \omega 7 c$ & 86.85 & 85.79 & 86.74 & 70.27 & 71.6 & 73.77 & 75.51 & 57.7 & 84.6 & 68.8 \\
\hline $\mathrm{C}_{18: 1} \omega 9 c$ & - & - & 0.84 & 2.54 & - & 0.76 & 0.89 & - & - & - \\
\hline Unknown & - & - & 2.58 & - & - & - & - & - & - & - \\
\hline \multicolumn{11}{|l|}{ Polar lipid } \\
\hline Phosphatidylcholine & + & + & + & - & ND & + & + & + & $\mathrm{ND}$ & $\mathrm{ND}$ \\
\hline Phosphatidylethanolamine & + & + & + & + & ND & + & + & + & ND & $\mathrm{ND}$ \\
\hline Phosphatidylglycerol & + & + & + & + & $\mathrm{ND}$ & + & + & + & $\mathrm{ND}$ & $\mathrm{ND}$ \\
\hline Diphosphatidylglycerol & + & + & - & - & $\mathrm{ND}$ & - & - & - & $\mathrm{ND}$ & $\mathrm{ND}$ \\
\hline Unknown aminolipid(s) & - & - & + & + & $\mathrm{ND}$ & + & + & + & $\mathrm{ND}$ & $\mathrm{ND}$ \\
\hline Unknown phospholipid(s) & - & - & + & + & ND & + & + & + & ND & $\mathrm{ND}$ \\
\hline Unknown lipid(s) & + & + & + & + & ND & + & + & + & ND & $\mathrm{ND}$ \\
\hline
\end{tabular}

ornithine, L-tyrosine, L-asparagine, citrate, acetate, fumarate and malate as carbon and energy sources, weakly positive for utilization of D-galactose, D-mannose, glycerol, inositol, $\mathrm{L}$-arginine and $\mathrm{L}-\alpha$-alanine and negative for utilization of

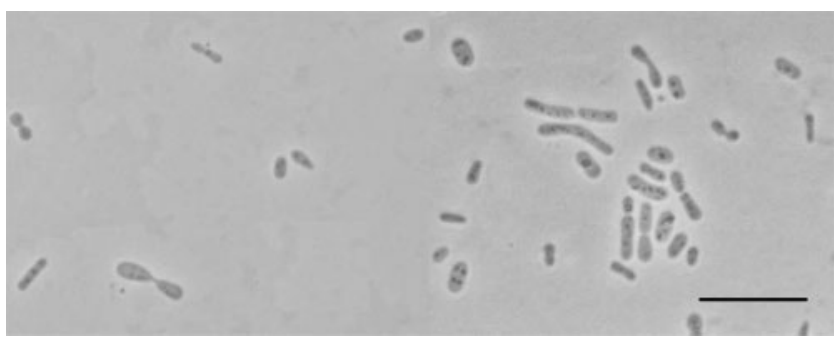

Fig. 2. Phase-contrast micrograph displaying cell morphology of strain $\mathrm{KMM} 9018^{\mathrm{T}}$ grown on MA for 2 days at $25^{\circ} \mathrm{C}$. Bar, $10 \mu \mathrm{m}$.
DL-leucine, DL- $\beta$-phenylalanine, DL-lysine, L-methionine and aminoacetic acid. Utilization of L-xylose is strain-dependent (type strain positive). Detailed fatty acid and polar lipid compositions are listed in Table 2. Susceptible to (amount per disc) ampicillin $(10 \mu \mathrm{g})$, benzylpenicillin (10 U), carbenicillin $(100 \mu \mathrm{g})$, gentamicin $(10 \mu \mathrm{g})$, rifampicin $(5 \mu \mathrm{g})$, streptomycin $(30 \mu \mathrm{g})$, vancomycin $(30 \mu \mathrm{g})$, nalidixic acid $(30 \mu \mathrm{g})$, ofloxacin $(5 \mu \mathrm{g})$, oxacillin $(10 \mu \mathrm{g})$, neomycin $(30 \mu \mathrm{g})$, oleandomycin $(15 \mu \mathrm{g})$, erythromycin $(15 \mu \mathrm{g})$, cephazolin $(30 \mu \mathrm{g})$, cephalexin $(30 \mu \mathrm{g})$, tetracycline $(30 \mu \mathrm{g})$ and chloramphenicol $(30 \mu \mathrm{g})$; resistant to kanamycin $(30 \mu \mathrm{g})$, lincomycin $(15 \mu \mathrm{g})$ and polymyxin $(300 \mathrm{U})$. The DNA $\mathrm{G}+\mathrm{C}$ content is $60.2-61.9 \mathrm{~mol} \%$ (thermal denaturation method).

The type strain is strain KMM $9018^{\mathrm{T}}\left(=\mathrm{NRIC} 0784^{\mathrm{T}}\right.$ $=\mathrm{JCM} 16874^{\mathrm{T}}$ ), isolated from a sample of shallow sediment collected from the Sea of Japan, Russia. A second strain of the species, KMM 9015, was isolated from the same sample. 


\section{Acknowledgements}

This study was supported by a grant from the Presidium of RAS 'Molecular and Cell Biology', by the Federal Agency for Science and Innovations of the Russian Federation (State Contract 02.518.11.7169) and by the Presidium Far-Eastern Branch of Russian Academy of Sciences (grant 09-III-A-06_227).

\section{References}

Arahal, D. R., Macián, M. C., Garay, E. \& Pujalte, M. J. (2005). Thalassobius mediterraneus gen. nov., sp. nov., and reclassification of Ruegeria gelatinovorans as Thalassobius gelatinovorus comb. nov. Int J Syst Evol Microbiol 55, 2371-2376.

Bruns, A., Rohde, M. \& Berthe-Corti, L. (2001). Muricauda ruestringensis gen. nov., sp. nov., a facultatively anaerobic, appendaged bacterium from German North Sea intertidal sediment. Int $J$ Syst Evol Microbiol 51, 1997-2006.

Buchan, A., González, J. M. \& Moran, M. A. (2005). Overview of the marine Roseobacter lineage. Appl Environ Microbiol 71, 5665-5677.

Collins, M. D. \& Shah, H. N. (1984). Fatty acid, menaquinone and polar lipid composition of Rothia dentosacariosa. Arch Microbiol 137, 247-249.

Ezaki, T., Hashimoto, Y. \& Yabuuchi, E. (1989). Fluorometric deoxyribonucleic acid-deoxyribonucleic acid hybridization in microdilution wells as an alternative to membrane filter hybridization in which radioisotopes are used to determine genetic relatedness among bacterial strains. Int J Syst Bacteriol 39, 224-229.

Folch, J., Lees, M. \& Sloane Stanley, G. H. (1957). A simple method for the isolation and purification of total lipids from animal tissues. J Biol Chem 226, 497-509.

Garrity, G. M., Bell, J. A. \& Lilburn, T. (2005). Order III. Rhodobacterales ord. nov. In Bergey's Manual of Systematic Bacteriology, 2nd edn, vol. 2C, p.161. Edited by D. J. Brenner, N. R. Krieg, J. T. Staley \& G. M. Garrity. New York. Springer.

Garrity, G. M., Bell, J. A. \& Lilburn, T. (2006). Rhodobacterales ord. nov. In List of New Names and New Combinations Previously Effectively, but not Validly, Published, Validation List no. 107. Int J Syst Evol Microbiol 56, 1-6.

Gerhardt, P., Murray, R. G. E., Wood, W. A. \& Krieg, N. R. (editors) (1994). Methods for General and Molecular Bacteriology. Washington, DC: American Society for Microbiology.

Labrenz, M., Collins, M. D., Lawson, P. A., Tindall, B. J., Schumann, P. \& Hirsch, P. (1999). Roseovarius tolerans gen. nov., sp. nov., a budding bacterium with variable bacteriochlorophyll a production from hypersaline Ekho Lake. Int J Syst Bacteriol 49, 137-147.

Lafay, B., Ruimy, R., Rausch De Traubenberg, C., Breittmayer, V., Gauthier, M. J. \& Christen, R. (1995). Roseobacter algicola sp. nov., a new marine bacterium isolated from the phycosphere of the toxinproducing dinoflagellate Prorocentrum lima. Int J Syst Bacteriol 45, 290-296.

Leifson, E. (1963). Determination of carbohydrate metabolism of marine bacteria. J Bacteriol 85, 1183-1184.

Marmur, J. \& Doty, P. (1962). Determination of the base composition of deoxyribonucleic acid from its thermal denaturation temperature. J Mol Biol 5, 109-118.

Martens, T., Heidorn, T., Pukall, R., Simon, M., Tindall, B. J. \& Brinkhoff, T. (2006). Reclassification of Roseobacter gallaeciensis RuizPonte et al. 1998 as Phaeobacter gallaeciensis gen. nov., comb. nov., description of Phaeobacter inhibens sp. nov., reclassification of Ruegeria algicola (Lafay et al. 1995) Uchino et al. 1999 as Marinovum algicola gen. nov., comb. nov., and emended descriptions of the genera Roseobacter, Ruegeria and Leisingera. Int J Syst Evol Microbiol 56, 1293-1304.

Owen, R. J., Hill, L. R. \& Lapage, S. P. (1969). Determination of DNA base compositions from melting profiles in dilute buffers. Biopolymers 7, 503-516.

Pearson, W. R. \& Lipman, D. J. (1988). Improved tools for biological sequence comparison. Proc Natl Acad Sci U S A 85, 2444-2448.

Romanenko, L. A., Schumann, P., Zhukova, N. V., Rohde, M., Mikhailov, V. V. \& Stackebrandt, E. (2003). Oceanisphaera litoralis gen. nov., sp. nov., a novel halophilic bacterium from marine bottom sediments. Int J Syst Evol Microbiol 53, 1885-1888.

Romanenko, L. A., Uchino, M., Falsen, E., Frolova, G. M., Zhukova, N. V. \& Mikhailov, V. V. (2005). Pseudomonas pachastrellae sp. nov., isolated from a marine sponge. Int J Syst Evol Microbiol 55, 919924.

Rüger, H.-J. \& Höfle, M. G. (1992). Marine star-shaped-aggregateforming bacteria: Agrobacterium atlanticum sp. nov.; Agrobacterium meteori sp. nov.; Agrobacterium ferrugineum sp. nov., nom. rev.; Agrobacterium gelatinovorum sp. nov., nom. rev.; and Agrobacterium stellulatum sp. nov., nom. rev. Int J Syst Bacteriol 42, 133-143.

Ruiz-Ponte, C., Cilia, V., Lambert, C. \& Nicolas, J. L. (1998). Roseobacter gallaeciensis sp. nov., a new marine bacterium isolated from rearings and collectors of the scallop Pecten maximus. Int J Syst Bacteriol 48, 537-542.

Sasser, M. (1990). Identification of bacteria by gas chromatography of cellular fatty acids, MIDI Technical Note 101. Newark, DE: MIDI, Inc.

Schaefer, J. K., Goodwin, K. D., McDonald, I. R., Murrell, J. C. \& Oremland, R. S. (2002). Leisingera methylohalidivorans gen. nov., sp. nov., a marine methylotroph that grows on methyl bromide. Int J Syst Evol Microbiol 52, 851-859.

Shida, O., Takagi, H., Kadowaki, K., Nakamura, L. K. \& Komagata, K. (1997). Transfer of Bacillus alginolyticus, Bacillus chondroitinus, Bacillus curdlanolyticus, Bacillus glucanolyticus, Bacillus kobensis, and Bacillus thiaminolyticus to the genus Paenibacillus and emended description of the genus Paenibacillus. Int J Syst Bacteriol 47, 289-298.

Smibert, R. M. \& Krieg, N. R. (1994). Phenotypic characterization. In Methods for General and Molecular Bacteriology, pp. 607-655. Edited by P. Gerhardt, R. G. E. Murray, W. A. Wood \& N. R. Krieg. Washington, DC: American Society for Microbiology.

Tamura, K., Dudley, J., Nei, M. \& Kumar, S. (2007). MEGA4: molecular evolutionary genetics analysis (MEGA) software version 4.0. Mol Biol Evol 24, 1596-1599.

Thompson, J. D., Gibson, T. J., Plewniak, F., Jeanmougin, F. \& Higgins, D. G. (1997). The CLUSTAL_X windows interface: flexible strategies for multiple sequence alignment aided by quality analysis tools. Nucleic Acids Res 25, 4876-4882.

Uchino, Y., Hirata, A., Yokota, A. \& Sugiyama, J. (1998). Reclassification of marine Agrobacterium species: proposals of Stappia stellulata gen. nov., comb. nov., Stappia aggregata sp. nov., nom. rev., Ruegeria atlantica gen. nov., comb. nov., Ruegeria gelatinovora comb. nov., Ruegeria algicola comb. nov., and Ahrensia kieliense gen. nov., sp. nov., nom. rev. J Gen Appl Microbiol 44, 201210.

Uchino, Y., Hirata, A., Yokota, A. \& Sugiyama, J. (1999 ). Ruegeria algicola comb. nov. In Validation of the Publication of New Names and New Combinations Previously Effectively Published Outside the IJSB, List no. 68. Int J Syst Bacteriol 49, 1-3.

Vandecandelaere, I., Segaert, E., Mollica, A., Faimali, M. \& Vandamme, P. (2008). Leisingera aquimarina sp. nov., isolated from a marine electroactive biofilm, and emended descriptions of Leisingera methylohalidivorans Schaefer et al. 2002, Phaeobacter daeponensis Yoon 
et al. 2007 and Phaeobacter inhibens Martens et al. 2006. Int J Syst Evol Microbiol 58, 2788-2793.

Wayne, L. G., Brenner, D. J., Colwell, R. R., Grimont, P. A. D., Kandler, O., Krichevsky, M. I., Moore, L. H., Moore, W. E. C., Murray, R. G. E. \& other authors (1987). Report of the ad hoc committee on reconciliation of approaches to bacterial systematics. Int $J$ Syst Bacteriol 37, 463-464.

Yoon, J.-H., Kang, S.-J., Lee, S.-Y. \& Oh, T.-K. (2007). Phaeobacter daeponensis sp. nov., isolated from a tidal flat of the Yellow Sea in Korea. Int J Syst Evol Microbiol 57, 856-861. 